\title{
Theology in the Dark: The Missionary Casuistry of Japan Jesuits and Dominicans during the Tokugawa Persecution (1616-1622)
}

\author{
Rômulo da Silva Ehalt
}

\begin{abstract}
About 18 years ago [...], a devil entered the body of a heathen and publicly declared he had come from England, and he had come to Japan to teach the devils of Japan how to persecute Christians. [...] since then this poor Church of Japan has been put to shame, and all those who protected the priests and their neighbors were executed and had their possessions taken away; not only those who sheltered and harbored [the missionaries] in their homes, but also ten neighbors of the house where they were harbored suffered the same punishment. [...] the door to that country is closed so tightly that it seems that, if this harsh persecution continues for long, everything will be lost. ${ }^{1}$
\end{abstract}

From his cubicle in Macau in 1622, the Portuguese Jesuit Afonso de Lucena (1551-1623) reminisced about his time in Japan. He had arrived there in 1578, about 30 years after Francis Xavier (1506-1552) and his companions started the mission. According to his account, the situation had worsened when a "possessed" English merchant, William Adams (1564-1620), arrived in Japan in the year 1600 . Adams successfully became close to the new rulers of the country, the Tokugawa clan. In Lucena's estimation, that was the spark which started the persecution against Jesuits, Dominicans, Franciscans, Augustinians, and Christians in general in the archipelago. ${ }^{2}$ The result was a decree in 1614 that expelled the missionaries: sixty-five priests, mendicant friars, and brothers embarked on three vessels to Macau, while 23 others took a ship to Manila. ${ }^{3}$

1 Lucena, De algumas cousas, ed. Schütte, 284. All translations are mine except when noted.

2 Concerning the political influence and land owned by Japan Jesuits in this period, see my text "From Tenants to Landlords". For an overview on William Adams and the Japanese, see Katō, "Aspects of Early Anglo-Japanese Relations", 31-59.

3 Shimizu et al. (eds.), Kinsei Nagasaki, 100-101; Schütte, Introductio, 200. 
Despite the order, 47 missionaries decided to stay. Living in hiding meant that the clergy no longer had a fixed residence. Those coming from Macau to Japan had to use Japanese vessels, given the strict vigilance over foreign ships imposed by local authorities, as well as to avoid Dutch and English merchants eager to denounce concealed missionaries. ${ }^{4}$ Once in the country, they had to quickly learn the art of disguise. While Japanese Jesuits could easily pass as laymen, that was not an option for their European peers. Although they could dress up as merchants in Nagasaki and other areas where foreigners were not an uncommon sight, non-Japanese missionaries needed to disguise themselves as commoners whenever wandering into regions farther removed from the port. ${ }^{5}$ In a letter to his brother, the Dominican Angel Ferrer Orsucci wrote that the priests used to dress like Spaniards, with a sword tied to the waist, long beards but no tonsure- a style that would later earn them the moniker "barbones" or big beards. ${ }^{6}$ Besides their attempts to blend in, missionaries also depended on the good will of Japanese Christians ready to risk their own lives to give them shelter as this act was considered a crime immediately after the expulsion decree. ${ }^{7}$ Once authorities began actively looking for hidden missionaries, the danger quickly escalated. In 1617, the Tokugawa Bakufu started collecting oaths in which signatories declared that they would not aid missionaries. ${ }^{8}$ The punishment represented being stripped of one's wealth and being sentenced to death. Moreover, the offender's family and up to nine neighbors could face the same fate. ${ }^{9}$ These severe restrictions turned what had been a question of survival into the most pressing moral challenge of the late 161os. How could missionaries justify the risk they imposed on Japanese Christians?

In 1620 , missionaries of the Jesuit administrative unit known as the Province of Japan submitted a questionnaire of 61 items to their counterparts in Macau. The Dominicans in Japan followed suit in 1621, with a similar-but much shorter-list of eight questions sent to the former rector of the Colegio de Santo Tomás in Manila. Both consultations dealt with the series of problems created by the oaths imposed on Christians in Japan. By focusing on these documents, this chapter explores the production of norms or rules for local

4 Ajuda, 49-V-7, fol. 173; JapSin 37, fols. 156-156v.

5 Schütte, Monumenta Historica Japoniae (hereafter MHJ), 793-794.

6 Anon., Lettere edificante, 38-39; Boxer and Cummins, "The Dominican mission in Japan", 41; Odstrčilík, "Between Languages", 121.

7 Orfanel, Historia Eclesiastica, cap. LIX, fols. 115v-116; JapSin 58, fol. 293.

8 Bakufu, literally "tent office", was the name given to the shogunate in Japan.

9 JapSin 17, fol. 287. However, as noted by Alvarez-Taladriz, this was not a juridical innovation, since it was customary in Japan to kill and confiscate the wealth of those who hid someone who had been ordered to be arrested. Alvarez-Taladriz, "Fuentes Europeas", 414. 
Christian communities in Japan and the use of moral theology in the process. The objective is to analyze both consultations as pieces of the dialogue here understood as missionary casuistry. This dialogue relied both on personal experience and theological authorities, while also considering circumstances imposed locally, with the ultimate aim of negotiating norms and confession guidelines with superiors outside of Japan. Considering the operations of both the Jesuits and the Dominicans in Japan, this chapter presents an in-depth appreciation of local conditions that determined the production of casuistry for the issue of the oaths imposed by the Tokugawa Bakufu on Christians in the late 1610 and early 1620 s Japan.

\section{$2 \quad$ Norm-Making through Missionary Casuistry}

Done by Jesuits and Dominicans in Japan during the persecution, wearing the attire of locals when in the land of infidels was an issue with a long history. By the early 17 th century, names such as the Dominican Domingo Bañez, as well as Jesuits Juan Azor and Tomás Sánchez, were among the most authoritative voices invoked by missionaries in Japan — and other regions — when justifying the adoption of non-Christian clothes. ${ }^{10}$ Similar issues were the object of the science known at the time as 'cases of conscience': a field dedicated to analyzing instances where a person had to make a correct moral choice between two or more possible courses of action. Doubts (dubia) concerning the moral acceptability of the available alternatives made great prudence necessary when considering what advice should be given by a priest to the individual facing the dilemma. ${ }^{11}$ As the Council of Trent put forward efforts to standardize liturgy and dogma, the increase in the number of situations met in missionary frontiers and colonial societies that could not be solved by classic medieval summas, or other materials available to priests and confessors abroad, led to a complex process of reformulation of the confessional practice during the 16th century that resulted in "high casuistry".12

10 Particularly useful for missionaries were the following passages: Bañez, Scholastica commentaria in secundam secundae, q. 3, a. 3; Azor, Institutionum moralium, vol. 1, lib. 8, c. 27, q. 4; Sánchez, Opus Morale in Praecepta Decalogi, vol. 1, lib. 2, c. 4, no. 16 and no. 20. But Japan Jesuits met severe criticism, both internal and external, when they decided to imitate Buddhist monks and wear their robes. On this issue: Brockey, "Authority, Poverty, Vanity", 185-195; Prosperi, "The missionary", 172-176; Alberts, Conflict and Conversion, 96. Tutino, Uncertainty in Post-Reformation Catholicism, 9 .

12 Schüssler, The Debate on Probable Opinions, 125-126. 
In areas of missionary activity and in colonial societies, problems such as inheritance, matrimony, the ownership of enslaved individuals, usury, idolatry, vows, penance, and how to administer and understand other sacraments, precepts, and dogmas comprised the bulk of issues that casuistry dealt with. ${ }^{13}$ In the study of the colonial enterprise led by the Portuguese Crown, the documental corpus of opinions and debates produced in colonial and missionary contexts has been collectively referred to by Giuseppe Marcocci as missionary casuistry, which he understands to be the vast system of integrated knowledge that allowed the emergence of a unified Portuguese empire. ${ }^{14}$

As in Europe, casuists outside the 'Old World' resorted to classic scholastic theologians and summists, as well as civil and canon lawyers..$^{15}$ However, in this context, a different notion of casuistry may be helpful; in a classic dictionary of philosophy, casuistry is defined both as the study of cases of conscience, as well as a "method of solving conflicts of obligations by applying general principles of ethics, religion, and moral theology to particular and concrete cases of human conduct". ${ }^{16}$ By taking casuistry as a dynamic science, rather than the accumulated archival set of questions, opinions, and responses, it is possible to imagine how casuists worked in colleges in Goa, Mexico, Macau, Lima, Malacca, Salvador, and Bahia. In these institutions, professors of cases of conscience were more than coaches to confessors; they were active producers of a theological discourse aimed at addressing the issues met in colonial societies - those under legal jurisdiction of the colonial empires - and in missionary frontiers-beyond the limits of colonial enterprises.

Take the example of Lopo de Abreu (1547-16o6), a Portuguese Jesuit who taught for more than two and a half decades in Asia. When he wrote his indipeta (petition for the Indies) letter in 1575, his plan was to leave Europe and work as a missionary in India or, if possible, in Japan. However, he ultimately became an established professor in Jesuit colleges in India. The highpoint of his career was his summa; written in the early 17 th century, it was met with wide acceptance in Asia but harsh criticism in Europe. Despite its critics, the work was later translated into Latin and could still be found in use in various Catholic colleges and churches throughout Asia until the end of the century. ${ }^{17}$ Casuists such as Abreu were part of an army of theological and legal polymaths

\footnotetext{
13 Wicki, "Problemas morais no Oriente Português", 257-258.

14 Marcocci, Linvenzione di un impero, 124; Marcocci, "Conscience and Empire", 487-488.

15 Schüssler, The Debate on Probable Opinions, 217.

16 Rolbiecki, "Casuistry", 46. See also the discussion in Jonsen and Toulmin, The Abuse of Casuistry, 11-16.

17 See my upcoming article on Abreu's Suma de Moral and its Latin translation, Vicente Álvares's Summa Lusitana.
} 
established in educational institutions outside of Europe, capable of resorting to rules and principles not derived from the accumulated volume of opinions and responses to previous questions, but rather from moral theology and civil and canon law. Their role, which still needs to be better understood, seemed to be that of an intermediary between tensions arising from the work and needs of missionaries and the projects and demands from superiors in Europe. As for the sources of casuistry itself, Rudolf Schüssler reminds us that even though there were no clear guidelines for how to apply these principles, judgements and discussions were at the core of casuistry and how it viewed moral dilemmas. ${ }^{18}$ In Asia, Abreu was just one from a list of little known casuists such as Francisco Rodrigues, António de Quadros, Gomes Vaz, Manuel de Carvalho, Domingos do Espírito Santo, Paulo da Trindade, Sebastião da Maya, Domingo González, Andrés Lopez, Arcadio do Rozário, and Juan de Paz, whose work and achievements the field is only beginning to grasp. ${ }^{19}$

By changing the definition of casuistry and considering the field in which it was used, missionary casuistry can be understood as the study of cases of conscience that arose from problems met in missionary settings, beyond the relative stability guaranteed by colonial dominance in certain cities, such as Goa, Malacca, Macau, or Manila. But it was more than that; in fact, it was a discourse formed by reports on the actions of missionaries and elaborated upon by theologians in colonial colleges, with the aim of negotiating with hierarchically superior authorities the validity of ad hoc decisions taken in the missions. Thus, the body of sources where missionary casuistry can be found involves, primarily, consultations from colonial or missionary settings addressed to superiors in these same areas or in Europe.

For that reason, missionary casuistry carried considerable political weight. The aim of solving moral problems in the missions involved much more than simply resolving dilemmas. It was indeed part of a political dialogue and negotiation between priests of the same order but in different hierarchical categories. Although it could be part of the job, it was not the ultimate goal of casuists to organize the jurisprudence of confessional issues and their solutions. Instead, their work was aimed at solving political and hierarchical conflicts between missionaries and their organizational units - provinces, vice-provinces, and so on - and superiors in Europe or other areas. Accordingly, missionary casuistry was a border-crossing science and discourse, oriented toward solving problems that arose in different local conditions. It was thus instrumental in exchanges

18 Schüssler, The Debate on Probable Opinions, 126.

19 Ehalt, "Casuística nos Trópicos", 399-418; McManus, "Limited-Term Servitude in Early Modern Nagasaki”. 
between missions in areas such as Japan, China, India, Brazil, Mexico, Peru, North America, and Africa, and hierarchically superior centers of power in Rome, Goa, Macau, Manila, and others. In addition, it formed the basis upon which inquiries were made concerning how to deal with issues met on the missionary front in order to avert unwanted attention from critics. The unity of this discourse was made possible because of a common language, shared by all involved parties, comprised of moral theology, as well as civil and canon law. Upon mastering these three corpora, casuists could then engage in missionary casuistry and the negotiations that ensued. Scholarship on Christian missions in early modern Japan has, for the most part, left aside the role of moral theology and casuistry in the relations between missionaries in the East and superiors overseas, thus overlooking how important mastering this linguistic and political code was. ${ }^{20}$

In the negotiation process between missionary peripheries and centers, Jesuits and Dominicans in Japan created numerous moral guidelines for Christian communities in the country, namely foreign residents and Japanese Christians. These groups were enmeshed in a complex set of different normativities and subjected to various authorities simultaneously, such as local legislations like Bakufu decrees, regional codes, and city or village ordinances; Portuguese royal officials; and the authority of various administrative entities and divisions in Japanese cities like ward administrators, city officials, Bakufu officials, and regional officials. Amidst this complex entanglement of different hierarchies and authorities, missionaries used missionary casuistry to influence the behavior of the faithful in Japan through the establishment of moral guidelines for Japanese Christians. In creating liturgical rules for those who wanted to lead a pious life, they also addressed issues that concerned Christian morals and canon law but were not regulated by Japanese legislation: trading practices, marriage, and slave trade and ownership, for example. In practice, these rules were regularly repeated by the members of these brotherhoods, forming constant reminders of what was to be expected from a Christian. ${ }^{21}$

Ultimately, missionary casuistry was significant because it gave authoritative normative value to local experiential reasoning. In the process of negotiating courses of action within Jesuit and Dominican ranks, missionaries put

20 For the case of Japan, exceptions include but are not restricted to the following: Ahn, Kirishitan Jidai no Kon'in Mondai; Asami, Kirishitan Jidai no Gūzō Sūhai; Takase, "Kirishitan Fukyō ni okeru Usura”; López Gay, El Matrimonio de los Japoneses; Pinto and Pires, "The 'Resposta que alguns Padres de Japão"; Ehalt, Jesuits and the Problem of Slavery; Ehalt, "Goa no Iezusukai"; Vu Thanh, "Introducing Tridentine Marriage".

21 See, for instance, the rules of the Confraria de Jesus. Murakami, "Kirishitan Kenkyū no Kaiko", 14. 
their own ad hoc decisions to the test. Under the enormous pressures put upon them by the intensification of the persecution in Japan in the early 17th century, their use of theology spoke to the need to obtain further support and recognition abroad, while at the same time it served as a tool for regulating Christian life during the persecution.

\section{The Underground Church}

Luís Yakichi (c. 1592-1622), his wife Lúcia (?-1622), and their sons André (c. 1615-1622) and Francisco (c. 1620-1622), were a Japanese Christian family living in Nagasaki. Behind their house, they had built a small chapel where they used to receive and hide missionaries. ${ }^{22}$ Despite their poverty, they would also let the space be used by other hiding Christians who wanted to confess whenever there was a priest there. Besides harboring missionaries, Luís Yakichi used to accompany them whenever they had to walk the streets seeking new refuge or places to hold mass. His dedication to the priests made him leave his home from time to time to travel with the missionaries in the Nagasaki region. Eventually, Luís Yakichi was arrested for trying to free the Flemish Dominican friar Lodewijk Frarijn or Luis Flores (c. 1563-1622) from the prison in Ōmura and was executed along with his family and seven other Christians on October 2, $1622 .{ }^{23}$

Following the expulsion of all missionaries in 1614, the Japanese Catholics and their pastors went underground. Like Luís Yakichi, numerous Christians helped hide missionaries during the persecution, a condition which European and Japanese alike referred to as hissoku (fisocu in Jesuit documents), i.e., "to be hiding, or enclosed, secluded, not going public". ${ }^{24}$ This led to two different outcomes. First, many Christians were executed for harboring missionaries. In 1622, when Luís Yakichi's family was killed, a total of 132 people had been executed in Japan due to the persecution. ${ }^{25}$ Out of 115 lay people, at least 64 were directly or indirectly related to the sheltering of priests. ${ }^{26}$ Second, priests

22 According to the 1615 annual letter from Japan, the number of small, private chapels had grown to such an extent in the city that there were "more churches now in Nagasaki than ever before". JapSin 58 , fol. 293 v.

23 Ruiz-de-Medina, Martirológio, 473-475; Japón 2, fols. 46-5o.

24 Anon., Vocabulario, fol. 95v. Hissoku was also the name of a punishment given to bushi, monks, and Shintō priests. It was a form of house arrest that would normally last for 30 or 50 days. See Fujii, Oshioki, 230-231.

25 Boxer and Cummins, "The Dominican Mission in Japan", 20.

26 Ruiz-de-Medina, Martirologio, 435-478. There were 17 missionaries executed that year. Gonoi, Tokugawa Shoki, 186. 
had to clandestinely recreate the way they administered the sacraments, held masses, and performed all the necessary liturgies required for the maintenance of Christian communities. In 1619, the Jesuit priest Francisco Vieira (1555-1619), Visitor of the Jesuit Province of Japan between mid-1618 and October of 1619, reported the situation in the following words:

We now have no house, no college, no residence, no parish in the villages that here are called inacas, nor any public church, because we do not have even a palm of land to call ours where we could stay without being discovered. Now we go from Christian house to Christian house, hiding, taking along our equipment and all necessary materials to hold mass, and in these Christian houses we erect a small altar, and while we are there hiding for one or two days, or a week, or a month, we hold mass, hear confessions, give communion to the Christians, and give sermons, and teach the Christians, and exhort them to persevere in the faith, and baptize those who have newly converted. All this we do in hiding, and perform the rest of the exercises as we used to do before in the churches when we had peace, in such a way that we are like a walking army with portable altars, helping the faithful with our ministries. ${ }^{27}$

Despite Vieira's rather optimistic view of the missionaries' activities under such circumstances, reality was in fact quite grim. In a report written the previous year, another Jesuit explained that all that priests could do was wait to be killed either by the sword or on a cross. ${ }^{28}$ In 1614 and 1615 , two military campaigns known collectively as the Siege of Ōsaka eliminated the last traces of the old opposition from the Toyotomi clan and consolidated the authority of the shōgun Tokugawa Hidetada (1579-1632). In September 1616, Hidetada turned his attention back to the religious problem and determined that local warlords - daimyō - were to have no Christians among their retainers. This led to a wide-spread prohibition against the presence of Christians..$^{29}$ However, aware of the inseparable relation between religion and trade, Hidetada tried to ensure the continuity of the commerce with European merchants. Portuguese and Spanish ships were restricted to Nagasaki, a city under direct shōgun

27 JapSin 17, fol. 195. Similar arguments were made by Vieira in a 1617 letter. See Brockey, Journey to the East, 69 .

28 JapSin 17 , fol. 177 .

29 Jesuit sources suggest that there were about 500,000 Japanese Christians in congregations and brotherhoods under the Society of Jesus' sponsorship prior to the expulsion of 1614, while in 1618 the number had fallen to about 300,ooo. See Schütte, Introductio, 433. 
authority, while Dutch and English vessels were instructed to harbor in Hirado, a small trading port ruled by the Matsura clan on the northwestern portion of Kyūshū. ${ }^{30}$ Missionaries, who up to that point had enjoyed an apparent tacit consent, at least in Nagasaki, now faced increasing pressure. In 1616, a small vessel (galeota) coming from Macau carried four missionaries: one Franciscan, one Dominican, and two Jesuits. While the two priests of the Society of Jesus left the ship before it docked in Nagasaki and managed to enter the city on a Japanese boat, the two mendicant friars tried to disembark disguised as merchants. Upon being alerted of their presence on the ship, the Nagasaki authorities stopped the friars and made them return to Macau on the same vessel, creating a public display of the changes in the policy toward missionaries. ${ }^{31}$

Amidst the chaos that ensued due to the growing persecution, lay brotherhoods played a fundamental role in arranging secure shelters for missionaries. These organizations first appeared in Japan in the 155 os as charitable confraternities following the model of the Portuguese Misericórdias and native Buddhist lay organizations. ${ }^{32}$ Lay brotherhoods, known as confrarias in Portuguese, cofradías in Spanish, or kumi in Japanese, organized under different parishes or by the initiative of missionaries, were established at various times in Japan as a direct response to persecution. ${ }^{33}$ That explains why they first appeared after 1587, when Toyotomi Hideyoshi signed an unenforced decree expelling missionaries from the country. ${ }^{34}$ By the early 17 th century, there were numerous such organizations in Japan. After the 1614 expulsion of missionaries, they became instrumental in keeping Christian communities together and addressing the difficulties that arose from the absence of priests. Although brotherhoods could not perform sacraments that needed the participation

\footnotetext{
30 Yamamoto, Tokugawa Hidetada, 141-144.

$31 \quad$ This seems to have been a different ship from the usual great ship from Macau to Nagasaki, given that financial disputes involving that year's Capitão-Mor, João Serrão da Cunha, prevented his vessel from leaving Macau. JapSin 58 , fol. 411; Boxer, The Great Ship from Amacon, 89; Gonoi, Tokugawa Shoki, 195.

32 For more on the Portuguese Misericórdias, see Sá, As Misericórdias Portuguesas, Sá, História Breve das Misericórdias, and Kawamura, Kirishitan Shinto Soshiki no Tanjō to Henyō.

33 That was also the impression Japan Jesuits had at the time. In the 1615 annual letter from Japan, Mateus de Couros comments on the direct correlation between persecution and the resurgence of brotherhoods. JapSin 58 , fol. $286 \mathrm{v}$.

Historians Ebisawa Arimichi, Kawamura Shinzō, and Reinier Hesselink have put forward different classifications of brotherhoods according to distinct criteria, although they mostly agree on the functions these organizations had under the Tokugawa persecution. See Ebisawa, Kirishitan no Dan'atsu, 125, 132; Kawamura, Making Christian, 41-55, 119, 134; Hesselink, "104 Voices", 247-248. For an overview of lay brotherhoods in Japan, see Costa, "The Misericórdias", 67-79; and Costa, "The Brotherhoods", 67-84.
} 
of ordained clergy, such as marriage, confession, and confirmation, they were fundamental for communities in observing the liturgical calendar, holding masses, and performing baptisms.

Some brotherhoods comprised wide networks of Christian communities organized under elder men and women as spiritual leaders. The better documented example of a brotherhood is that of the Jesuit Confraria de Nossa Senhora da Assunção or Santa Mariya no Onkumi, named after the day upon which Xavier arrived in Japan. According to the records written in 1618 by Jerónimo Rodrigues in Macau, the organization gathered, under the auspices of the Society of Jesus, numerous Christian lay leaders, dividing them into a plethora of minor, major, and universal brotherhoods: minor organizations had about 50 male members plus their wives and servants; above them, major brotherhoods gathered minor organizations and had about 500 to 600 members; lastly, universal brotherhoods gathered all the major organizations from a single district. ${ }^{35}$ Most of these brotherhoods owed allegiance to a single religious order or were run by priests from a given order. Nevertheless, in many cases, that did not mean brotherhoods would deny aid to missionaries of orders different to that of their sponsors. Christians would help missionaries by performing various tasks such as delivering messages or letters, offering them food and shelter, transporting them by sea or land, and searching for new places to hide. Not only that, brotherhoods also created spaces for praying and gatherings, like the chapel behind Luís Yakichi's house, some of which even housed relics obtained from the sites of martyrdoms. For example, Manuel Murayama (1596-1620), one of the sons of the disgraced Nagasaki magistrate António Murayama Tōan (1562-1619), who was executed in 1619 for harboring priests, preserved five martyrs' bodies in his house as well as 80 fingers from Christians killed because of their faith, all collected by servants of the family from various martyrdom sites. ${ }^{36}$

Because of the difficulty faced by priests in visiting and administering the sacraments to Japanese Christians, brotherhoods assumed most of the liturgical duties that could be performed without priests. In order to maintain some degree of uniformity in the different underground churches, they were often regulated by sets of rules written by the missionaries, which could allow them to perform some rituals, including communal prayer. ${ }^{37}$ Some of the extant

35 JapSin 59, fol. 165a. This structure resembles the organization implemented by China Jesuits for their missions. Particularly valuable is the comparison drawn by Brockey between lay groups and parishes. Brockey, Journey to the East, 329-330.

36 After his own martyrdom on July 24,1620 in Nagasaki, when he was beheaded alongside two brothers and a nephew, all relics were bequeathed to Dominican and Franciscan friars. Ruiz-de-Medina, Martirologio, 425 . 
statutes include those for brotherhoods such as the abovementioned Jesuit Confraria de Nossa Senhora da Assunção or Santa Mariya no Onkumi, the Jesuit Confraria de Santa Maria or Santa Mariya no Kumi, the Jesuit Confraria de Jesus or Zezusu no Kumi, the Dominican Cofradia del Nombre de Jesus or Zezusu no Mina no Onkumi, and the Franciscan Sesuta-kō. ${ }^{38}$ Generally, there were no rules expressly defining the sheltering of missionaries as an obligation, but a Jesuit proposal sent in the early 1620 os to Rome suggested that plenary indulgences should be given to those that harbored or helped missionaries to find shelter in Japan. ${ }^{39}$

It is unclear whether members of Japanese brotherhoods ever clashed with each other, but the competition between mendicant orders and Jesuits for the allegiance of these organizations was evident. Furthermore, the existence of numerous brotherhoods, each associated with a different order, led to much suspicion regarding the validity of their practices. Mateus de Couros, Jesuit Provincial of Japan between 1617 and 1621, was highly suspicious of non-Jesuit organizations. In a 1619 letter, Couros denounced Franciscan brotherhoods for "accepting some [men] who are in reality living away from their real wives and having affairs with other women, absolving many to whom we have denied absolution", as well as "making preachers out of ignorant and secular young men, who spread numerous and grave errors, often heresies". He also accused friars of founding brotherhoods with the sole intention of "taking from our hands all the Christian communities we have spent so many years creating" 40

In 1617, Japan Jesuits tried to prove locals' preference for priests and brothers of the Society of Jesus. They submitted a bundle of 75 affidavits signed by 755 Japanese lay leaders, collected from all over the southern island of Kyūshū to the northeastern region of Tōhoku. Swearing allegiance to the Society of Jesus' missionaries and certifying the priests' commitment to each community, the documents were certified by the Jesuit Provincial. ${ }^{41}$

Dominicans, who had been in the Nagasaki area since 16o9, adopted a similar strategy a few years later. Between 1621 and 1622, friar Diego Collado (c. 1587-1641) personally traveled and gathered the signatures of numerous lay

38 JapSin 59, fols. 165-173; Murakami, "Kirishitan Kenkyū no Kaiko", 10-15; Schütte, "Futatsu no Komonjo", 135-147; Los Angeles [Rueda], Virgen S. Mariano, 195-225; Nawata-Ward, Women Religious Leaders, 338-344; Kawamura, Making Christian, 133; Kawamura, Kirishitan Shinto Soshiki, 296-383; Delgado García, El Beato Francisco de Morales, 39-44.

39 Gonoi, Tokugawa Shoki, 195; Ramos, "Renier sa foi", 196; JapSin 22, fol. 258v.

$40 \mathrm{MHJ}, 817$. Couros could be referring to the case of the Confraria da Cruz, founded by the secular priest Francisco António Murayama (?-1615). After the priest's death in the Siege of Ōsaka, the organization was overtaken by the Dominicans and merged with the Dominican Cofradia del Santo Nombre de Jesus. Delgado García, El Beato Francisco de Morales, 40. 
leaders of the various Cofradías del Rosário, although only a handful of these documents survive. ${ }^{42}$ The collection of letters, as well as two sets of rules of Jesuit brotherhoods and other papers, were taken by Collado to Madrid in order to discredit the Society of Jesus and end their monopoly in Japan. ${ }^{43}$ But while the signatories of the Jesuit documents put their names under a short and very standardized text, the Rosário brotherhood's letters revealed a lot more about their commitment to the priests. ${ }^{44}$

In December 1621, 18 members of the Shimabara Rosário signed a document stating their willingness to shelter missionaries from whichever religious order. $^{45}$ An early 1622 letter from the six elders of the Rosário of the village of Chijiwa revealed that the Jesuit Giacomo Antonio Giannone had exhorted them to leave the Rosário and join Jesuit brotherhoods. ${ }^{46}$ In March of the following year it was the turn of the 104 elders of the Nagasaki counterpart of the same brotherhood to sign a similar document. According to the Nagasaki brothers and sisters, the offering of rewards for missionaries by the city's authorities had led many people to search for the priests. These people entered houses forcefully, searching neighborhoods for missionaries. For that reason, the brotherhood worked "to provide [the missionaries] with places to stay and other necessities, each according to his or her individual capacity and circumstances". ${ }^{47}$ Moreover, the document explained that, because of the dedication of the Dominicans, most of them had been arrested, unlike what was happening to the Jesuits at the time. A couple of months later, the Ōmura Rosário brotherhood issued a similar statement. Signed by 77 members residing in areas surrounding Nagasaki, it declared that 25 of the Rosário members had been executed for aiding missionaries of all orders, meeting their martyrdoms "with true joy". However, it extensively praised the Dominican missionaries, who were, according to the letter, "sleeping in the fields and making mountains their home" in order to tend to the Christian community. ${ }^{48}$ As evidence

42 However, a better understanding is needed regarding what influence the long tradition of the Rosary brotherhoods had in the Japanese organizations in comparison to those created by Jesuit initiative. Klötter, The Language of the Sangleys, 38-42; Menegon, Ancestors, Virgins, \& Friars, $57-58$.

43 Doñas, "Órdenes Religiosas en Japón", 55.

44 On the Collado papers, see Matsuda, Kinsei Shoki Nihon, 1146-1276.

45 Matsuda, Kinsei Shoki Nihon, 1169.

46 Matsuda, Kinsei Shoki Nihon, 1171.

47 Matsuda, Kinsei Shoki Nihon, 1173. See also, Hesselink, "104 voices", 267-269; Boxer and Cummins, "The Dominican mission in Japan", 22.

48 Matsuda, Kinsei Shoki Nihon, 1184-1185. Twenty-four Christians were executed in the Ōmura region between 1617 and early 1622 , that is to say, since the persecution against Christians helping missionaries increased and the Ōmura Rosário letter was penned. 
of their dedication, the letter mentions that most Dominicans in Japan at the time were in prison.

Although there were probably other Rosário letters such as these, the large discrepancy between the number of signatories of the Jesuit papers and the Dominican papers reveal that while the mendicants had gained a strong foothold in Nagasaki since the start of the persecution, Jesuits maintained their influence on local Christian communities elsewhere. The existence of a network of Christians spread throughout Japan guaranteed to missionaries of all orders in Japan at this time a safety net of allies in their constant search for refuge and sustainment.

\section{The Jesuit Consultation of 1620}

In the late 1610 s and early 1620 s, Japan Jesuits faced competition with the non-Jesuit orders for the hearts and souls of Japanese Christians and were also confronted with internal disputes. Created in 1549 with the arrival of Xavier to the archipelago, the Jesuit mission in Japan was elevated to Vice-Province in 1583 and Province in $1611 .{ }^{49}$ In October of 1614, a few weeks before the Bakufu expelled them from the country, the missionaries gathered on Japanese soil for the final Jesuit Provincial Congregation..$^{50}$ After that, radical changes brought by the expulsion made any kind of gathering virtually impossible in Japan.

Internally, members of the Jesuit Province of Japan were divided by the East China Sea. By September of 1620, there were 28 priests and brothers of the Province in Japan, 70 in Macau, and 21 spread through Cochinchina, India, and Malacca. Distance created a lot of suspicion between those in the archipelago

This number, however, includes those who were not associated with Dominican but with Jesuit brotherhoods, thus it is necessary to take the " 25 martyrs" affirmation with a pinch of salt. See Ruiz-de-Medina, Martirologio, 375-376, 378, 392, 398-401, 422, 432-435.

49 Initially, the mission of Japan and the Vice-Province of Japan were subordinated to the Province of India, created in 1552 and split into Province of Goa and Province of Malabar or Cochin in 1605. Hélène Vu Thanh, "Principles of Missionary Geography in Jesuit Spirituality and their Implementation in Japan (16th-17th centuries)", Bulletin of Portuguese/ Japanese Studies 18/19 (2009), 178; Maria de Lurdes Ponce Edra de Aboim Sales, Do Malabar às Molucas: os Jesuítas e a Província do Malabar (1601-1693), doctoral dissertation, Universidade Nova de Lisboa (2015), 17.

50 Congr. 55, fols. 270-279b. The first congregation was held in 1592 , while the third took place in 1598. Both were organized under extraordinary circumstances, given that Japan was not a Jesuit province at the time. 
and those in Macau. ${ }^{51}$ In October of 1620 , the Jesuit priest Cristóvão Ferreira (c. 1580-1650) alerted the Superior General Claudio Acquaviva about a purported scheme by China Jesuits to celebrate a congregation of the Province of Japan in the Colégio da Madre de Deus of Macau. According to him, their plan was to hold a vote in the congregation and make decisions without the participation of the elders of Japan. ${ }^{52}$ The Provincial of Japan, Couros, was also vehemently against holding the congregation in Macau. Sharing most of Ferreira's sentiment toward China Jesuits, Couros feared he could not trust those who had passed from the Vice-Province of China to his province. He also believed that since the number of Jesuits in Macau who had taken the fourth vow was not sufficient and they had little to no experience of Japan, a congregation without the presence of the provincial would not be able to properly address the needs of the missionaries. ${ }^{53}$ The grave crisis of trust between Japan Jesuits on the background of the 1620 consultation was worsened by their disputes with China Jesuits. The Vice-Province of China, first created in 1615 by Acquaviva and established de facto in 1619, relied on the help of a number of Christian Mandarins but was mainly supported by the finances of the Province of Japan which, in turn, depended on the profits from their participation in the Nagasaki-Macau trade. ${ }^{54}$ Eventually, the congregation was delayed until 1623 , when it was held in Macau.

Despite all difficulties, a handful of Jesuit elders of the Province of Japan gathered at the Colégio da Madre de Deus in Macau on July 8, 1620 to analyze the list of 61 questions collected from their colleagues in Japan. ${ }^{55}$ Visitor Vieira was probably the one responsible for taking the questionnaire to China. ${ }^{56}$ The consultation was held without Couros - and possibly without his consentnor any of the provincial's consultants or any of the rectors in Japan. According to Ferreira, the meeting was endorsed by consultants of the visitor, who claimed to be consultants of the Province of Japan (consultores da província),

$5^{1} \quad$ JapSin 25, fol. 125; JapSin 37, fol. 156; Ajuda, 49-V-7, fols. 183-186v, 191-194, Schütte, Introductio, 238.

$5^{2}$ JapSin 17 , fol. 263 .

53 JapSin 37, fols. 19ov-191. The fourth vow of obedience to the pope taken by Jesuit priests was, and still is, a particular feature of the Society of Jesus. For the historical genesis and context of the vow, see O'Malley, "The Fourth Vow in Its Ignatian Context".

54 Brockey, Journey to the East, 58, 64-66, 73, 437.

55 Ajuda, 49-VI-6, fols. 120-153, "Perguntas $q[$ ue $]$ os $P[$ adr $]$ es de Japam fizeram no tempo da perseguição aos $P[a d r]$ es de Macao, com Reposta destes a ellas". There is also a Latin version bearing a Portuguese title: "Repostas [sic] de alguãs duuidas $q[$ ue] no tempo da perseguição de Jappão se mandarão perguntar a Macao no anno de 1620". Vanves, GBro 94, fols. $5^{-20}$.

$5^{6} \quad$ JapSin 17 , fol. 248. 
a title that the priest denounced as inaccurate, since Vieira had died soon after coming back to Macau. ${ }^{57}$

The list presented numerous possible answers to the questions it contained, suggesting the goal was to check the validity of decisions that had already been taken in Japan. In general, there were no clear categories dividing the questions, but the focus was mainly on liturgy, confessions, social obligations of Japanese Christians, their participation in martyrdoms, public oaths, and the external use of non-Christian signs. The assembly, following previous examples of similar consultations, resorted to a number of theological authorities to support their claims. There were, of course, references to classic authorities such as Silvestro Mazzolini, Angelus Prierias, and Martín de Azpilcueta, but there were also citations from more recent manuals such as those by Thomás Sanchez, Luis de Molina, and Juan de Azor. ${ }^{58}$ Interestingly, there were also a couple of references to the Suma de Moral, the theology textbook written by Lopo de Abreu, mentioned earlier. His textbook on cases of conscience in India appeared in at least two catalogues of Jesuit libraries in Macau in the first half of the 17 th century. ${ }^{59}$ While most issues presented did not have precedents in previous consultations and congregations, the consultants took the opportunity to review the problem of the confession of the sick, an issue that had been debated by the second and third Congregations of Japan, in 1592 and $1614 .{ }^{60}$

Most of the questions referred to specific problems faced by Christians and the clergy in Japan during the persecution. For instance, how could missionaries perform mass without candles made of bee's wax, or without proper assistants? Could an arrested priest celebrate mass without a fire? Or by himself, while in hiding? ${ }^{61}$ There was also plenty of uncertainty regarding the confessions of arrested Christians-could they accept written confessions, or displays of contrition via hand gestures, or could they hastily hear confessions before a martyrdom?62 ${ }^{62}$ There were also numerous doubts about what made one a martyr; should a Christian who threw themselves into the fire during an execution of others be considered a martyr? ${ }^{63}$ What about Christians who were arrested for various crimes and refused to apostatize in exchange for their

\footnotetext{
57 JapSin 17 , fols. $255,263 \mathrm{v}$.

$5^{8}$ In a probable reference to the second or even third volume of the manual, Jerónimo de Angelis wrote that Azor's Institutionum moralium arrived in Macau in 1619. JapSin 34, fol. 40.

59 Recent scholarship on these libraries include Golvers, "The Library Catalogue" and "Circulation and Reception".

6o Ajuda, 49-VI-6, fols. 126v-128.

61 Ajuda, 49-VI-6, fols. 120-122v.

62 Ajuda, 49-VI-6, fols. 122v-125v.

63 Ajuda, 49-VI-6, fols. 138v-139.
} 
pardon? ${ }^{64}$ Could a Christian who did not want to disclose their finances to the authorities, in order to protect properties and other Christians, be considered a martyr? ${ }^{65}$ There were yet several questions dealing with difficulties faced by Japanese Christians who needed to hide their faith and abide by orders from heathen lords, which could lead them to commit hurtful actions toward other Christians. For example, could they help destroy churches? Could they help tie up imprisoned fellow Christians in preparation for their martyrdom? Could they provide firewood for the martyrs' fires? ${ }^{66}$ Could they listen to Buddhist sermons when ordered to by their lords? Could they take Christian prisoners to be executed and help by throwing their bodies into the sea? How should the Christians who helped burn two families in 1613 in Arima be treated? ${ }^{67}$ These very concrete situations show how Christians in Japan were torn between social obligations to Japanese lords, their allegiance to the numerous Christian brotherhoods, and faithfully following the doctrines of their faith.

There are a number of topics questioning actions taken by Japanese converts to hide their faith by portraying themselves as non-Christians. For instance, there is mention of the custom of hanging an ofuda, a slip of paper or tablet placed at the entrance of a house that could indicate, among other things, that its residents were affiliated to a Buddhist temple or a Shintō shrine-were Christians allowed to hang ofuda in their houses? ${ }^{68}$ Of course, the problem was more than hiding one's Christian faith behind a Buddhist or Shintō tablet.

64 Ajuda, 49-VI-6, fol. 139 .

65 Ajuda, 49-VI-6, fols. 132v-133.

66 According to the Dutch observer Ryan Gysbertsz: "When anyone is to be burnt, it is given out and publicly proclaimed on the evening before, that each House which lies near the place where the burning is to take place, must bring 2, 3, 4 or 5 faggots of firewood, more or less, according as to whether there are many or few persons to be burnt". Boxer, $A$ True Description, 74 .

67 The dramatic martyrdom of the Hayashida family and Taketomi Kan'emon Leo and his son, Taketomi Dan'emon Paulo, was considered the first in which Christians were burnt at the stake in Japan. See Anesaki, A Concordance, 31; Ruiz-de-Medina, Martirologio, 325326.

68 Ajuda, 49-VI-6, fols. 129-129v; Ramos, "Renier sa foi", 192. I thank Martin Nogueira Ramos for clarifying the reference to the ofuda in the document. Letters from the period indicate that the word fuda (without the honorific o-) could also refer to the kōsatsu, tablets posted in public spaces to inform the population of government determinations and legislation, although this is unrelated to the context here. See MHJ, 905. The use of the ofuda in Nagasaki seems to be connected with the resurgence of Shinto beliefs in previously Christian areas of the region such as the Ōmura fief. See Kudamatsu, Kirishitan Denraichi no Jinja, 254-263. The increasing use of these tablets and leaflets made Collado discuss their acceptability in his confessor's manual, published in 1632. Hino (ed.), Koryaado Zangeroku, 20, 156, 266-267. 
Jesuits considered the use of the ofuda to be a public denial of their faith, an act condemned by Azor and Sánchez. ${ }^{69}$

Effectively, these two authors guide most of the discussions regarding the confession of the faith. A precept directly linked to the first of the Ten Commandments, the obligation to confess the Christian faith, was discussed by Thomas Aquinas (ST II-II, q. 3, a. 2), who considered it necessary for the salvation of the soul and concluded that to not confess one's faith was a mortal sin. After Aquinas, numerous theologians discussed the circumstances that could allow a Christian to avoid this obligation. ${ }^{70}$ In India, Abreu considered that tyranny could be reason enough to allow Christians to avoid the obligation of the precept, although he did not permit the use of non-Christian symbols to hide one's faith. ${ }^{71}$ Here, like the Jesuits in Macau, Abreu also referred to Azor's and Sanchéz's conclusions, indicating the circumstances they listed allowing, for instance, the use of clothes or languages to hide one's faith when in pagan or heretic regions. ${ }^{72}$ In the end, the Japanese policy that forced Christians to sign oaths stating that they would not shelter missionaries, was at least partially viewed in Macau as an issue of faith confession.

In early 1617 , the shōgun Tokugawa Hidetada decided that all Christians helping or harboring priests in Japan would be executed along with the missionaries. According to Gonoi Takashi, the purpose was to put into practice the September 18, 1616 "Decree Against the Christian Religion" (Bateren Shümon Goseikin), which sought to continue the Bakufu's anti-Christian policy after the death of Tokugawa Ieyasu (1543-1616) by restating his prohibition against the presence of Christians in Japan. ${ }^{73}$ Effectively, between the enactment of the decision and October of 1617, when that year's Portuguese ship left Nagasaki for Macau, one Franciscan friar, one Jesuit priest, one Augustinian friar, and one Dominican friar, as well as at least six lay assistants, were executed. The first execution of Japanese Christians who aided missionaries happened

69 Azor, Intitutionum moralium, vol. 1, lib. 8, cap. 27, q. 1; Sánchez, Opus Morale in Praecepta Decalogi, vol. 1, lib. 2, cap. 4.

70 See, for instance, Mazzolini, Summa Silvestrina, verbo Fides, q. 5; Angelus, Summa Angelica, verbo Fides, no. 8.

$71 \quad$ BC, TF-HS 79, fols. $26-28$.

72 Azor, Intitutionum moralium, vol. 1, lib. 8, cap. 27, q. 4; Sánchez, Opus Morale in Praecepta Decalogi, vol. 1, lib. 2, cap. 4, n. 20. Similar rules regarding clothing were still valid among hidden Christians as late as the late 18th century, when Japanese authorities seized numerous documents describing these regulations. See Ramos, La foi des ancêtres, 74; Anesaki, Kirishitan Shümon, 233-234.

73 Gonoi, Tokugawa Shoki, 196-197. There are numerous transcriptions of this decree. See, for example, Shimizu et al. (eds.), Kinsei Nagasaki, 113-114. 
on October 1, 1617. Gaspar Ueda Hikojirō (?-1617) and André Yoshida (?-1617), who had harbored the Dominican friar Alonso de Navarrete and the Augustinian friar Fernando Ayala, were decapitated in a small island at the entrance of the Bay of Nagasaki. ${ }^{74}$ However, while the friars were killed in Ōmura, the area where they were found, those who had helped them were purposefully transported to and executed in Nagasaki. ${ }^{75}$ The beheading made clear to the residents of the city what would happen to those who dared to shelter missionaries.

The following year, the new Nagasaki Governor (bugyō), Hasegawa Fujimasa (?-1630), also known by the alias Gonroku, started the rigorous enforcement of the decree. ${ }^{76}$ If in February of that year the Jesuit Visitor Vieira wrote that the persecution was against "the shepherds, not the sheep", by the end of the year things had changed entirely. ${ }^{77}$ In 1618 alone, at least 12 people were executed for sheltering missionaries. Two sailors, one Nagasaki otona, or ward administrator, and their families—including seven children —-were killed on November $25^{78}$

The pressure grew exponentially after January of 1619 , when Domingos Jorge, a Portuguese resident of the Bunchi-machi ward of Nagasaki, was arrested, along with a number of neighbors and members of his brotherhood, for harboring the Jesuit priest Carlo Spinola. ${ }^{79}$ The realization that foreign residents were also helping missionaries led Gonroku to force all citizens of Nagasaki, Japanese and foreign, to abide by and sign, on January 22/23, 1619, a public oath swearing they would harbor no missionary in their house. ${ }^{80}$ To extend the policy to foreign residents was nothing out of the ordinary-in early 17th-century Japan, the notion of nation or people (kokumin) included all those who resided in Japan and were subjected to the authority of the shogunate. ${ }^{81}$

74 Ruiz-de-Medina, Martirologio, 373-374; JapSin 17, fol. 104v.

75 Gonoi, Tokugawa Shoki, 195.

76 On Gonroku's past, see Hesselink, Dream, 174-175.

77 JapSin 17 , fols. $238-238$ v.

78 Ruiz-de-Medina, Martirologio, 395-397. The Nagasaki otona were responsible for one ward or street $(c h \bar{o})$ each.

79 JapSin 59, fol. 175v. Domingos Jorge was burnt to death on November 18, 1619. His wife and four-year-old son were killed later that year in the Great Martyrdom of Nagasaki. Ruiz-deMedina, Martirologio, 418 and 459. When Spinola was arrested, the Jesuit Visitor Vieira and his companion, priest Ferreira, were staying at a house in the same neighborhood where the arrest took place, forcing them to flee in the middle of the night. JapSin 17, fol. $238 \mathrm{v}$. Since Spinola and another Jesuit who was also arrested the same night, Ambrósio Fernandes, were both procuradores of the Province of Japan, numerous Jesuit accounting books were forfeited and lost to Nagasaki authorities on that occasion. JapSin 38, fol. 49 .

8o See Amaro, Kōshi Nagasaki, 17o. Alvarez-Taladriz, "Fuentes Europeas", 414.

81 The place of residence was key to determining allegiance, belonging, and subjection. See Matsui, "Jendaa kara Miru", 95. 
According to Vieira, Nagasaki officials would arrest anyone slightly foreign-looking that they could find on the city streets at night. However, he also suggested that the anti-Christian sentiment of Nagasaki authorities was only a smoke cloud to fool Bakufu authorities in Edo. According to Vieira, Gonroku tried negotiating with Japanese Christian otona so they would surrender all hidden missionaries in order to avoid the destruction of Nagasaki and its population. Certainly, Vieira's view credits the Christian tenacity of the Japanese otona for deepening the antagonism toward the tyrannical rule of the Bakufu, represented by the bugyō and his officials in Nagasaki, thus reinforcing the idea of profound opposition between the long-suffering Christian community and the Japanese central authorities. Since the otona denied handing missionaries over to the authorities, Gonroku decided to make all citizens sign the oath. This transformed Nagasaki into the perfect setting for martyrdoms because the clear opposition between tyrannical rule and Christian perseverance turned all executions into acts of defiance and resistance. According to Vieira, 30 silver bars, which had been publicly displayed in Nagasaki in Kurusu-machi (the "ward of the Cross") as a reward for the capture of thieves, were now also offered to anyone who reported priests or friars. ${ }^{82}$ Here, Jacinto Orfanell, the Dominican chronicler who later became a martyr himself, pointed out the irony that the official responsible for keeping the silver was a Japanese Christian member of a lay brotherhood. In Orfanell's narrative, the official recused himself, thus becoming another heroic figure of Japanese Christianity. ${ }^{83}$

The issue of the oath imposed by Japanese authorities in Nagasaki was mentioned a few times during the 1620 debate in Macau, albeit indirectly. For instance, the questionnaire addressed the problem of arrested converts who were put in jail for reading spiritual books to their communities-an activity often promoted by lay brotherhoods - and had the opportunity to sign an oath denying help to missionaries in exchange for their freedom. ${ }^{84} \mathrm{On}$ the one hand, to sign such papers would be the equivalent of consenting to the very act of persecution, while refusing to sign, on the other hand, could elevate the spirits of those to whom the arrested Christian read spiritual books in the first place. ${ }^{85}$ In fact, the questionnaire also explained that such oaths included a

$82 \quad$ Kataoka Yakichi highlights that it was not until 1633 that rewards would be offered for the capture of brothers, while rewards for the capture of apostates who had returned to the Christian faith were offered starting in 1682. Kataoka, "Hakugaika no Kirishitan", 9.

83 Ajuda, 49-IV-6o, fols. 8o-8ov; JapSin 17, fol. 238v; Hesselink, Dream, 178; Orfanel, Historia Eclesiastica, cap. LIX, fol. 115v; Gonoi, Tokugawa Shoki, 197-198; Alvarez-Taladriz, "Fuentes Europeas", 414. Vieira evaluated the 30 bars were worth more than 120 cruzados. JapSin 17, fol. 238v.

84 Gonroku had imposed a prohibition against the reading of Christian books at the same time he started enforcing the no-harboring policy. See Ajuda, 49-IV-6o, fol. 8o.

85 Ajuda, 49-VI-6, fol. 148. 
provision stating that those who signed it would also refuse to teach the Christian doctrine. ${ }^{86}$ Notably, the consultation referred to the specific situation of Christians already imprisoned for breaking the law-reading spiritual books and disseminating the Christian faith - but failed to address the larger issue of Christians being forced to sign these oaths in the first place.

The questionnaire also points to an interesting fact: the widespread implementation of these oaths against the harboring and aid of missionaries in Japan. This meant that Japanese Christians traveling from one place to another were constantly asked about their faith. More specifically, the questionnaire asked whether Christians ought to respond honestly when inquired by innkeepers about their religious affiliations. Jesuits debated whether Christians could use ambiguity or amphibology to avoid constantly putting their lives at risk. Coined by Martín de Azpilcueta, this rhetorical tool turned out to be a valuable device in a number of situations. ${ }^{87}$ Japan Jesuits, convinced of the value of amphibology and supported by Azor and Sánchez's arguments, justified its use in Japan, as long as the innkeeper and any other person questioning the Christian were not official authorities. Thus, the consultation concluded that Japanese Christians could answer ambiguously in order to protect themselves in these situations. ${ }^{88}$

Since there were numerous Christians in the Nagasaki administration, there were also some who faced difficulties following orders that directly threatened converts. The questionnaire described that when Gonroku started the oath policy, there were Christians directly involved with collecting signatures. ${ }^{89}$ Called yokome, these were the officials responsible for announcing legal decisions to the population in Nagasaki and guaranteeing the observance of laws. ${ }^{90}$ Since the policy promoted apostasy, Jesuits in Macau severely condemned the participation of Christian officers in this process.

86 Ajuda, 49-VI-6, fol. 140v.

87 Perez Zagorin, Ways of Lying, 170-171.

88 Ajuda, 49-VI-6, fols. 143-143v. By the late 18 th century, Japanese Christians considered that, even though they were obliged to confess their faith in the past, that was no longer the case during the harsh persecution of the Edo period. See Anesaki, Kirishitan Shümon, $86,230-232$.

89 Ajuda, 49-VI-6, fols. 140v-141.

9o It seems they were subjected to the same hierarchy of the metsuke or "inspector", who were directly subjected to the Bakufu, although they often came from local bushi families. The yokome and the metsuke played a fundamental role in the legislative and executive process in the region. Yasutaka, Kinsei Nagasaki, 74-75; Ōmura-shishi (ed.), Shin'hen Ömura, $176-179$. The 1620 consultation also suggests that the yokome were in charge of guarding condemned Christians on their way to their martyrdom. Ajuda, 49-VI-6, fol. 136v. 
In the end, the 1620 consultation did not overtly endorse the signing of the oaths imposed by authorities. The particular circumstances surrounding the missionaries and their allies during the persecution guaranteed them a vast network of Christians, including economic and politically powerful individuals, that were willing to help. However, the implementation of the oath policy by Gonroku in 1618 severely curtailed the choices of missionaries in Japan, leading many to seek the help of poor people living in small huts. ${ }^{91}$

Despite the executions of citizens harboring missionaries between 1617 and 1620, Japan Jesuits were confident that they would have no trouble finding shelter whenever they traveled into the countryside. It seems this was particularly true in areas inhabited by generations of Christians, such as Nagasaki, Shimabara, or Amakusa. Provincial Couros felt there was no shortage of Christians willing to risk their lives to support the priests around the port city. ${ }^{92}$ However, most Japanese Christians who opened their doors to the missionaries were poor. Jesuits believed, and rightly so, that only those who had no real estate or revenues dared to risk their lives to protect the clergy, since they had nothing material to lose if caught. ${ }^{93}$ Other foreigners in Japan were also aware of these difficulties. A Dutch account of the period speaks of missionaries had to hide in holes in the ground under floorboards, covered by mats and planks, or in small spaces inside walls and, when the persecution grew stronger, they had to resort to hiding in lepers' huts. ${ }^{94}$

\section{$5 \quad$ Dominican casos de conciencia between Nagasaki and Manila}

While Jesuits could count on an expansive network of Christian communities, Dominicans were in a much more perilous situation. Though a part of the influential Province of Our Lady of the Most Holy Rosary in the Philippines, which enjoyed wide support from the Spanish administrators, their numbers in Japan dwindled in comparison to those of the Jesuits: by mid-1621, there were 25 Jesuit priests versus eight Dominican friars in Japan. Even worse for the friars, out of these eight, six were imprisoned, with a seventh, José de San

$91 \quad$ As did Ferreira in Kyūshū in the 1620s, when "moving in the shadows between huts on that island's remote mountains". Brockey, The Visitor, 388.

92 MHJ, 793.

93 мHJ, 833 .

94 Boxer, $A$ True Description, $78,84$. 
Jacinto Salvanés, captured later that year, thus leaving the controversial Collado the only Dominican not in a jail cell in Japan. ${ }^{95}$

Among those arrested was a key figure of the Dominicans in Japan: the superior of the mission, Francisco de Morales (1567-1622). He arrived in 1602 at the southernmost area of the island of Kyūshū, in the fief of Satsuma. Under the Shimazu rule, Morales and the other Dominicans preached and built churches until May of 16o9, when they were expelled and forced to flee to Nagasaki. ${ }^{96}$ There, Morales managed to gain the support of the powerful Murayama clan and build the Santo Domingo church in July of 16o9. Five years later, when the Bakufu ordered the expulsion of the missionaries, he tricked the authorities by embarking on a ship that left Nagasaki but returned immediately after. That marked the start of a period of five years during which Morales hid in the house of André Murayama Tokuan (?-1619), son of António Murayama Tōan, magistrate (daikan) of the outer wards of Nagasaki between 1602 and $1616 .{ }^{97}$ According to Reinier Hesselink, an informant pointed out to officials that the house of a cloth dryer was likely holding a hidden missionary. A raid in the night between March 14/15, 1619 led to the arrest of another Spanish Dominican, friar Alonso de Mena (1578-1622). Under torture, Mena's servant betrayed "the information that there was another friar hiding in the residence of Tōan's eldest son, Tokuan. The same day, Morales [...] was seized at the Murayama residence". ${ }^{98}$ By this time, Morales was among the senior missionaries of the country. He had participated in about two decades of missionary work in Satsuma and Nagasaki, he spoke the language, and he had as much knowledge about the Japanese as did any Jesuit at the time. ${ }^{99}$

On September 10, 1622, Morales' life was interrupted: he had been sentenced with 24 other missionaries, as well as 30 laymen and women, to be decapitated and burnt to death in what became known as the Great Martyrdom of Nagasaki. ${ }^{100}$ However, between his arrest and tragic end, Morales kept up his correspondence with fellow Dominicans in Nagasaki and Manila. ${ }^{101}$ Using materials

95 Boxer and Cummins, "The Dominican mission in Japan", 71. On Diego Collado, see Tronu, "The Rivalry", 25-39; Doñas, “Órdenes Religiosas en Japón", 51-92.

96 Aduarte and González, Tomo Primero de la Historia, 326.

97 Boxer and Cummins, "The Dominican mission in Japan", 13-14.

98 Hesselink, Dream, 179.

99 Boxer and Cummins, "The Dominican mission in Japan", 17.

100 Ruiz-de-Medina, Martirologio, 443-464. Andrew Ross argues that, until 1622, Christians were executed through various methods (decapitation, burning, etc.) by different local rulers, but that year Hidetada initiated a massive campaign to suppress Christianity. See Ross, $A$ Vision Betrayed, 82.

See, for instance, his five letters written from prison in Anon., Lettera edificanti, 7-16. 
such as smuggled pens, ink, and a cheap type of tissue paper, the so-called hanagami (literally, nose-paper), the friar also wrote theological opinions. ${ }^{102}$ With this improvised stationery, Morales managed to send his opinions to Domingo González (1574-1647), rector of the Colegio de Santo Tomás in Manila between 1612 and 1616 and a famed theologian in the Philippines. ${ }^{103}$

González was well acquainted with the doctrinal problems of Christianity in Japan. His papers included at least one long discussion on martyrdoms in the country, which was probably written in this period. ${ }^{104}$ In addition, it is believed he had previously visited the country. ${ }^{105}$ In June of 1621 , almost a year after the Jesuit consultation in Macau, González reviewed a series of eight issues submitted from Japan. Although much shorter than the Japanese consultation, topics included, for example, the participation of Christians in the destruction of churches, sales of gunpowder and foodstuffs to the Dutch, and marriages between Spaniards or Portuguese men and Japanese women in Japan. The fourth question on the list referred to the problem of harboring missionaries. More importantly, González transcribed an opinion sent from prison by Morales. ${ }^{106}$

The text begins with González's summary of the issue. According to him, Nagasaki authorities were aware that missionaries were hiding in the city and demanded the oaths to appease pressures from the Bakufu. This echoes the explanation of Jesuit Visitor Vieira, described above, regarding the anti-Christian sentiment of Gonroku toward the Christians of the city, according to whom the governor himself was not against the believers, but merely following orders. ${ }^{107}$ González describes Gonroku, by contrast, as an unwilling enforcer of the law, who wanted to avoid any responsibility for any missionaries found in Nagasaki. As for the Christian population, González thought that they had no real intention of abiding by the terms of the imposed oaths and claimed that Christians signed the documents solely out of instinct for self-preservation. According to González, these unspoken circumstances led some Christians to

102 Boxer and Cummins, "The Dominican mission in Japan", 49.

103 González would be rector again three more times, between 1626 and 1633, 1639 and 1641, and 1643 and 1645. See Aduarte and González, Tomo Primero de la Historia, 147-158.

104 APSR, Miscelanea 1, fols. 52-96 and Consultas 2, fols. 320v-327v; Ehalt, "Goa no Iezusukai", $1-14$.

105 Boxer and Cummins, "The Dominican mission in Japan", 71.

106 See the "Cassos Resueltos por el Padre Fray Domingo Gonçalez Rector de Collegio de S ${ }^{\text {to }}$ Thomas Para Iapon", Consultas 2, fols. 317-320.

107 JapSin 17, fol. 238v. Boxer wrote: "The humane character of Hasegawa Gonroku [...] is fully attested by other contemporary sources both Catholic and Protestant". Boxer, A True Description, 130 . 
believe that they could sign said oaths with a clear conscience, while others argued that taking the oaths could not be condoned since the policy itself was motivated by hatred against the Christian faith (odium fidei). The Dominican agreed, however, that the actions of authorities such as Gonroku should be condemned by the Church, even though their ignorance of the dogma could eventually safeguard their consciences. Yet, the most important issue was not the actions of Japanese authorities, but whether Christians themselves should be allowed to take the oath. Here, González referred to a "very knowledgeable and prudent" opinion on the subject submitted by Morales from prison, which he then reproduced. ${ }^{108}$

Morales had recognized that the ideal course of action would be to denounce the Christians who took the oaths imposed by the Japanese authorities and to celebrate as martyrs those who had lost their lives refusing to do so. Nevertheless, he believed that it was not up to missionaries to force believers to choose martyrdom. ${ }^{109}$ For the imprisoned theologian, the threat of harm or death was enough to allow believers to sign the pledges without actually being obliged to follow its terms. He recognized the oaths as contracts that created a natural obligation (estoy obligado de iure nat [ura] li sub [poena peccati] mortali), but because the oaths themselves were unjust (iniuste), Morales argued that the tyrannical nature at the origin of the pledges, and especially the threat of capital punishment, were sufficient reasons for considering them void. ${ }^{110}$ Morales was certainly aware of the theories concerning the voidability of contracts of the time, which is exemplified in works such as Leonardus Lessius' (1554-1623) De iustitia et iure (1605). ${ }^{111}$

For Morales, the oath could only be taken if there was no sincere intention on the part of the Christian individual to abide by it, and solely when they had been threatened with death or loss of possessions. Their real intention on taking the oaths should be to avoid further angering the tyrant ruler of Japani.e., the shoggun Hidetada. That was, according to him, the common opinion of many experienced and learned priests of Japan, although it is unclear whether he included Jesuits in the same lot. ${ }^{112}$ Japanese Christians themselves shared the same understanding, as shown by an anonymous confession from this period where the believer declared that by signing the "useless and empty"

\footnotetext{
108 Consultas 2, fol. 317v.

109 Consultas 2, fol. $318 \mathrm{v}$.

$110 \quad$ Consultas 2, fol. 318.

111 For more on Lessius, see Wim Decock, Theologians and Contract Law: The Moral Transformation of the Ius Commune (ca.1500-1650), 261-263.

112 Consultas 2, fol. 318v.
} 
oath he was not committing a sin nor "signing any real oath, but merely something serving to fool the pagan official".113

The distinction between intention and action used by Morales suggests he had Thomas de Vio's (Cajetan's) understanding of promise (promissio) in mind, according to which one could say-or, in this case, sign under-the words "I will do" without necessarily assuming a binding promise, unless the one promising was "motivated by a true animus promittendi [the intention to assume a compromise]".114 This lack of obligation behind promises, implicit in the act of taking the oath imposed by Nagasaki authorities, was what Morales used to redirect the intentions behind the action itself and argue in favor of the morality of the Christian community's self-defense strategy.

Taking the oath was not an invitation for Japanese and foreign Christians in Nagasaki to sin. Considering Aquinas' division of scandals into active and passive, Morales explained that there was no active scandal, given that Christians were taking the pledges just as priests would have advised them to. As for passive scandals, he asked the addressee of his letter-González— - to verify if there was any adequate theological rule for the case of Japan that would be accepted. ${ }^{115}$ Considering scandals among non-Christians, though, he affirmed that the taking of the oath was seen not as a rejection of the faith or of the priests, but rather as an ingenious artifice or action-a saikaku-taken by the believers out of prudence. Much worse than signing the oath would be, in his words, to betray where missionaries were hiding, for that was "the work of Judas" ("pues és officio de Judas"). Moreover, he defended that missionaries were not supposed to criticize or denounce a Christian for refusing to give shelter to one of them, as they were not abiding by the oath but simply seeking to preserve their own lives. ${ }^{116}$

The theologian believed that the main reason behind Christians choosing to take the oath was what decided if their actions were morally acceptable. Morales understood that their intention was to avoid violating a decree from the shōgun ("el mandado de la Tenca") and being sent into exile, as well as safeguarding not only their own lives but also those of their neighbors. In fact, Morales explained that those who took the oath, in their own right (utitur jure suo), were also protecting all those in their own jüningumi. ${ }^{117}$ The jūningumi

\footnotetext{
113 Hesselink, "104 Voices", 254.

114 Decock, Theologians and Contract Law, 180.

115 Consultas 2, fol. 318v. See Summa Theologiae IIa-IIae, q. 43, a. 2.

116 Consultas 2, fol. 319. There had been at least one case of a Christian (Lino Sashikata Tōemon) who was killed at home in 1619 by officials of the daimyō of Ōmura for refusing to sign the oath. His wife and kids were spared, though, and handed over to another household. See Ruiz-de-Medina, Martirologio, 399.

Consultas 2, fol. 318v.
} 
("ten-person group") was a collective of ten households organized under a leader, the kumigashira. Common all over Japan since the early 17th century, these groups were responsible for collecting taxes and organizing festivals and religious ceremonies, as well as neighborhood surveillance. ${ }^{118}$ Besides their civil obligations, the whole jüningumi was held responsible for crimes committed by any member of the group. These were the ten neighbors referred to by the Jesuit Lucena in the excerpt at the beginning of this chapter. ${ }^{119}$ It has been argued that, in the fall of 1621, the system was replaced in Nagasaki by the goningumi ("five-person group") in order to facilitate the identification of hidden missionaries. ${ }^{120}$ But there are still references to jüningumi in the city as late as 1633 among Japanese sources, which suggests that at least during this 13-year period there was a mixed system of five- and ten-person groups in different areas of Nagasaki. ${ }^{121}$ Furthermore, from the point of view of Japanese authorities, executing a whole jūningumi meant a drastic reduction in revenue from tax collection. Thus, the change in 1621 could also have been motivated by financial reasons in an attempt to avoid the loss of fiscal revenues, similar to the measures taken by the authorities of the neighboring fief of Arima around the same time..$^{122}$

118 Irimoto, “Jūningumi no Seiritsu", 163-200, especially 171; Yasutaka, Kinsei Nagasaki, 332.

119 Japanese sources put the beginning of the jūningumi in Nagasaki as 1618, although Léon Pagès wrote that when André Yoshida (?-1617) and Gaspar Ueda Hikojirō (?-1617) were arrested for harboring priests, the August 21, 1617 arrest order against them included the imprisoning of all the heads of neighboring houses, who, according to Pagès, "had been associated in groups of ten for many years". Pagès also understood that the 1616 anti-Christian decree would punish the "five closest neighbors" of those harboring priests, although he does not provide his source. Irimoto, "Jūningumi no Seiritsu", 171, 19o. Pagès, Histoire 1, 338, 369-370; Ruiz-de-Medina, Martirologio, 373-374.

120 Hesselink, "104 Voices", 247; Hesselink, Dream, 188.

121 Irimoto, "Jūningumi no Seiritsu", 190-191. Referring to a 1628 martyrdom, Ryan Gysbertsz describes that "five householders" were punished along with the person harboring a priest. Boxer, A True Description, 84. Finding the geographical limits of this mixed system would considerably help to identify what areas authorities considered to be more problematic in Nagasaki.

122 Furthermore, it was common to have jüningumi in the cities and goningumi in smaller villages. Irimoto, Goningumi to Kinsei Sonraku, 30-32. Returning to Morales' opinions, the threat of executing a whole jüningumi was far from empty: as the Dominican was writing from prison, all members of a Nagasaki jūningumi were beheaded on November 27, 1619 after priests were found in their neighborhood. Additionally, at least seven members of the same jüningumi from the Nagasaki outer ward of Hama-no-machi along with five of their relatives were executed with Morales in the 1622 Great Martyrdom of Nagasaki. Ruiz-de-Medina, Martirologio, 419-422, 445-446, 458, 461-464; Pagès, Histoire 1, 369-37o. For more on the martyrdom of Antonio Coreia from Hama-no-Machi, see Hesselink, Dream, 196-201. 
Morales also believed that, if the oaths were not taken, the shoggun could coerce all Christians in a locality to apostatize. The relation between both measures-forced apostasies and the punishment against the goningumi or jüningumi - is clear, for instance, in a letter written by Gonroku to a local official on December 15, 1618, in which he mentioned orders from the shōgun to forcefully convert every single Christian of Nagasaki to Buddhism and confirmed his intentions to continue tracking any missionaries hidden in the city. ${ }^{123}$ These two goals characterized the Bakufu's policy toward the Christian population of Nagasaki in this period, and their success depended largely on the collection of oaths taken by the city's residents.

Accepting the imposition of the local government and taking the oaths meant, for Morales, not only protecting the various jūningumi of the city from undeserved punishment but of the Christian community as a whole. He argued that, if priests were to advise against the oaths, more fervent Christians would be put in harm's way. In general, a reduction in the numbers of Christians in Japan, particularly the more devout believers, would mean that missionaries would have fewer places to hide and the whole community would be jeopardized by the weakening of local lay brotherhoods. ${ }^{124}$

Days after the September 1622 martyrdom of Nagasaki, Christians were still lurking around the execution site in search of relics. Leading a defiant group of believers, a Christian woman called Ines was caught - perhaps not unexpectedly — by the guards of Gonroku. After being tied to a post and tortured, she begged to be killed like the priests, since not only was she a Christian, but she had also harbored missionaries herself. ${ }^{125}$ Ines' pleas illustrate that Japanese Christians were aware that giving shelter to missionaries was one of the main reasons behind the martyrdom of lay believers. After all, at least 19 of the 30 Japanese Christians executed in the Great Martyrdom of Nagasaki were directly or indirectly related to the harboring of priests. ${ }^{126}$

\footnotetext{
123 Shimizu et al. (eds.), Kinsei Nagasaki, 120. Effectively, on December 13, 1618, Gonroku conducted a thorough search for hidden missionaries and forced all residents to sign new oaths. Hesselink, "104 Voices", 246.

124 Consultas 2, fols. $318 \mathrm{v}-319$.

125 Pardo San Francisco, Relación Verdadera, fols. 44v-45.

126 Ruiz-de-Medina, Martirologio, 443-464. That was also the perception of a Dutch observer at the time. See Boxer, $A$ True Description, 73 .
} 
But while the open persecution of priests and friars terrorized missionaries and Japanese Christians alike, subtle changes influenced their prospects, too. Shadowed by dramatic events such as the Great Martyrdom of Nagasaki, the year of 1622 marked the return of Miyajiri Santō Dayū, an oshi or guide specialized in taking pilgrims to the Grand Shrine of Ise, who had been absent from the region of Ōmura and Nagasaki since at least $1574 \cdot{ }^{127}$ The reemergence of the traditional Shintō guide after a hiatus of 48 years marked both the beginning of a return to previous beliefs and the resurgence of a more socially acceptable religious option for the local population. Shintō shrines popped up in Nagasaki during this period — seven in the 162os, two in the 163os, and seven more in the $1640{ }^{128}$ Of course, the rhythm of construction of Shintō shrines pales in comparison to the more than 30 Buddhist temples opened between 1620 and $1650 .{ }^{129}$ As the Nagasaki landscape and its surroundings changed, Christians and missionaries gradually lost their safe havens while being killed off. The Bakufu's persecution tested the faith and tenacity of numerous converts and, amidst apostasies and the arrest and execution of numerous laymen and women, missionaries were hunted down.

With the increasing pressure placed on them by the oaths, Jesuits and Dominicans struggled, each in their own way, to find appropriate solutions. On the one hand, the Society of Jesus dealt with the consequences of the policy by treating the oaths as issues of confession of the faith. Insofar as they avoided bringing the very topic of oath-taking to the debate, thus imposing its tacit acceptance to the addressees of their consultation, they placed focus on the circumstances that allowed the alleviation of the obligations imposed by the precept. On the other hand, Dominicans had a much more direct approach to the topic, highlighting the contractual nature of oaths and questioning their voidability. By and by, in their negotiations with superiors in Rome and Manila, both Jesuits and Dominicans agreed that the tyrannical nature of the Japanese rule was enough to both invalidate the oaths and allow Christians to refuse to answer when their faith was questioned by other Japanese people.

The hierarchical organization of both orders was crucial to the decision-making process as well as to the way moral issues were addressed in Japan. The Jesuits' rigid structure often demanded the holding of meetings where issues were compiled into consultations sent to external authorities,

\footnotetext{
127 Kudamatsu, Kirishitan Denraichi, 275; Kudamatsu, Nagasaki no Ise Shinkō, 34-35.

128 Almost half of the Shinto shrines in Nagasaki can be traced back to the early Edo period. Kudamatsu, Kirishitan Denraichi, 274-276.

129 Hesselink, Dream, 187.
} 
be they in Macau, Goa, Rome, or various Jesuit universities and colleges across Europe. At the same time, however, Jesuit brotherhoods functioned as enforcers of norms determined locally and later confirmed outside of Japan. Dominicans, however, worked differently. First, the 1621 Dominican document refers to much fewer problems - only eight questions-than the 61 questions of the Jesuit questionnaire. The difference certainly arose from the way the consultations were formulated, since the Dominican process involved only two interlocutors, while the Jesuit consultation was the central piece of a negotiation process between those in Macau and their superiors in Rome. In the end, the small size of the Dominican mission in Japan allowed them to engage in personal dialogues when addressing more problematic issues - which included, for example, the difficult topic of marriage in Japan. ${ }^{130}$ As a result, deep theological issues were discussed in private correspondence.

The issue of the oaths imposed by the Bakufu was a matter of life and death in the late 1610 s and early 1620 in Japan. Possibly due to its importance, González and Morales had well-defined roles in their discussion: While the arrested theologian offered his experience of Japan, the Dominican in Manila confirmed the validity of Morales' decisions. However, González did not concern himself with citing a summa, manual, or treatise, despite the imprisoned friar's request for authoritative arguments. His role, as he understood it, was to accept and reproduce the authority of Morales' experience, at least in regard to the oath issue. In fact, the source suggests that there was an ongoing debate between both friars. Ultimately, the way Jesuits and Dominicans organized their theological debates spoke to how each order understood the dynamics of normative production and community administration.

Jesuit priests and Dominican friars alike understood Japanese Christianity as in its infancy. ${ }^{131}$ Moreover, it was subjected to what they perceived as an almost prototypical tyrannical rule that worked in odium fidei, harshly persecuting the country's Christians and clergy. Under these circumstances, Japanese Christianity could be said to be doomed to be perfect; its desperate situation formed the ideal example of religious tenacity for Christians in other areas. This allowed for unorthodox responses to a variety of different norms,

\footnotetext{
130 Consultas 2, fols. 317-317v. See also the discussion by Coutinho Silva (Chapter 6) in this volume.

131 The González-Morales debate clearly refers to the infancia ecclesia, that is to say, the primitive state, that characterized Japan in this period. Consultas 2, fol. 317v. The topic is recurrent in numerous documents of the period. Jesuits made these observations since the early days of the mission and there are numerous references to Rome in Jesuit literature in Japan. See McManus, "Imperial History without Provincial Loyalty?".
} 
from confessional guidelines to local political decisions, that had to be greatly improvised at times. Thus, in the government of Christian consciences during the period of persecution in Japan, theological authorities were overshadowed by local experiences, individual initiatives, communal expectations, hierarchical tensions, and extraordinary conditions.

\section{Acknowledgements}

I would like to thank the Japan Society for the Promotion of Science for the funding for this research (JSPS International Research Fellowship, P19015), and the anonymous reviewers for their comments. I am also grateful for the help provided by Ryan D. Crewe (University of Colorado Denver), who kindly offered me the Dominican documents from Manila used in this chapter. For suggestions and corrections on various stages of writing, I extend my gratitude to Ishizaki Takahiko (Hitachi-no-kuni Sōshagū, Ishioka, Japan), Manuel Bastias Saavedra (mplhlt, Frankfurt am Main), and Regalado Trota Jose (University of Santo Tomas, Manila). I am especially grateful to Liam Matthew Brockey (Michigan State University) and Martin Nogueira Ramos (École Française d'Extrême Orient, Kyoto) for sharing their thoughts on this article. Japanese names are noted in the order commonly used in Japan (family name followed by given name, without a comma between), including Japanese scholars (as in Matsuda Kiichi). The names of Japanese Christians are noted with the Christian name first, followed by family name and Japanese given name, whenever available (as in Bartolomeu Ōmura Sumitada).

\section{Bibliography}

\section{Manuscripts}

Archives jésuites en France, Vanves, France, Brotier Collection (GBro), 94.

Archivo de la Universidad de Santo Tomás, Central Library, Manila, Philippines

Archivo de la Província del Santíssimo Rosário (APSR): Consultas 2, Japón 2, Miscelanea, vol. 1.

Archivum Historicum Societatis Iesu, Rome, Italy, Japonica-Sinica (JapSin), 16, 17, 22, $25,34,37,38,58,59$.

Biblioteca do Palácio Nacional da Ajuda, Lisbon, Portugal, Jesuítas na Ásia (Ajuda), 49-IV-6o, 49-V-7, 49-VI-6.

Tilburg University Library, Tilburg, Netherlands, Brabant Collection (вС), TF-HS 79. 


\section{Printed Sources}

Aduarte, Diego de, and González, Domingo, Tomo Primero de la Historia de la Provincia del Santo Rosario de Filipinas, Japon, y China, de la sagrada orden de Predicadores, Zaragoza 1693: Domingo Gascon.

Aquinas, Thomas, Summa Theologiae.

Anon., Lettere edificanti scritte dai frati predicatori martirizzati nel Giappone ed inseriti nel catalogo de beati dal regnante sommo pontefice Pio IX raccolte e pubblicate perfare seguito al commentario istorico già edito di loro vita e martirio, Rome 1868: Bernardo Morini.

Anon., Vocabulário da Lingoa de Iapam com adeclaração em Portugues, feito por alguns padres, e irmãos da Companhia de IESV, Nagasaki 16o3: Collegio de Iapam da Companhia de Iesus.

Azor, Juan, Institutionum moralium, in quibus vniuersae quaestiones ad conscientizam rectè, aut prauè factorum pertinentes, breuiter tractantur, Pars Prima, Rome 16oo: Luigi Zanetti.

Bañez, Domingo, Scholastica commentaria in secundam secundae angelici doctoris $D$. Thomae, Quibus, quce ad Fidem, Spem, \& Charitatem spectant, clarissimè explicantur, Venice 1587: Altobello Salicati.

Carletti, Angelo, Summa Angelica de casibus conscientialibus, Venice 1578: Egidio Regazola.

Los Angeles [Rueda], Juan de, Virgen S. Mariano Tattoqi Rosario no xuguiôto, vonajiqu Iesus no Mina no Cofradiani ataru riacuno qirocu, Binondoc (Philippines) 1622.

Mazzolini, Silvestro, Summa Sylvestrinae quae Summa Summarum mérito nuncupatur, Lyon 1551: Jacobo Giunta.

Orfanel, Jacinto, Historia Eclesiastica de los Sucessos de la Christandad de Iapon, desde el año de 1602, que entro en el la Orden de Predicadores, hasta el de 1620, compuesta por el Padre Fray Iacinto Orfanel, de la misma Orden, y Ministro antiguo del Santo Evangelio en aquel Reyno, Y añadida hasta el fin del año de 1622 por el Padre Fray Diego Collado, Vicario Provincial de la dicha Orden en el dicho Reyno, Madrid 1633: la viuda de Alonso Martin.

Pardo San Francisco, Diego de, Relación Verdadera, y Breve de la Persecución, y Martirios que padecieron por la confession de nuestra Santa Fee Catholica en Iapón, quinze Religiosos de la Prouincia de S. Gregorio, de los Descalços del Orden de nuestro Seraphico P. San Francisco de las Islas Philipinas. Aonde tambien se trata de otros muchos Martires Religiones, y seculares de diferentes estados. Todos los quales padecieron en Iapon desde el año de 1613 hasta el de 1624, la qual escriuio, y embiô a la dicha Prouincia Fray Diego de San Francisco Predicador de la misma Prouincia, y Comissario del Iapon, Manila 1625: Thomas Pimpin.

Sánchez, Tomás, Opus Morale in Praecepta Decalogi, Madrid 1613: Luis Sánchez and Juan Hasrey. 


\section{Literature}

Ahn Jung Won, Kirishitan Jidai no Kon'in Mondai, Tokyo 2012.

Alberts, Tara, Conflict \& Conversion: Catholicism in Southeast Asia, 1500-1700, Oxford 2013. Alvarez-Taladriz, Jose Luis, "Fuentes Europeas sobre Murayama Toan (1562-1619), II-Murayama Toan Antonio, según Bernardino de Avila Girón”, in Kōbe Gaidai Ronsō 17 (1966): 395-418.

Amaro, Bébio Vieira, Kōshi Nagasaki ni okeru Kirishitan Shisetsu ni Kansuru Kenkyū [Research on Christian Structures in the port-city of Nagasaki], (PhD Thesis), Tokyo 2016.

Anesaki, Masaharu, A Concordance to the History of Kirishitan Missions (Catholic Missions in Japan in the Sixteenth and Seventeenth Centuries), Tokyo 193 o.

Asami Masakazu, Kirishitan Jidai no Gūzō Sūhai, Tokyo 2009.

Boxer, Charles Ralph, A true description of the mighty kingdoms of Japan and Siam by François Caron and Joos Schouten, London 1935.

Boxer, Charles Ralph, The Great Ship from Amacon-Annals of Macao and the Old Japan Trade, 1555-1640, Lisbon 1963.

Brockey, Liam Matthew, "Authority, poverty, and vanity: Jesuit missionaries and the use of silk in Early Modern East Asia”, in Anais de História de Além-Mar XVII (2016): 179-222.

Brockey, Liam Matthew, A Journey to the East: The Jesuit Mission to China, 1579-1724, Cambridge (US) and London (UK) 2007.

Brockey, Liam Matthew, The Visitor: André Palmeiro and the Jesuits in Asia, Cambridge (US) and London (UK) 2014.

Costa, João Paulo Oliveira e, "The Brotherhoods (Confrarias) and Lay Support for the Early Christian Church in Japan", in Japanese Journal of Religious Studies 34:1 (2007): $67-84$.

Costa, João Paulo Oliveira e, "The Misericórdias among Japanese Christian Communities in the 16th and 17th Centuries", in Bulletin of Portuguese-Japanese Studies 5 (2002): 67-79.

Decock, Wim, Theologians and Contract Law: The Moral Transformation of the Ius Commune (ca.1500-1650), Leiden 2012.

Delgado García, José, El Beato Francisco de Morales OP mártir del Japón (1567-1622) Su personalidad histórica y misionera, Madrid 1985.

Doñas, António, “Órdenes Religiosas en Japón: Diego Collado y el Memorial de 1631”, in Liburna 13 (2018): 51-92.

Ebisawa Arimichi, Kirishitan no Dan'atsu to Teikō [Persecution and Resistance of the Kirishitan], Tokyo 1981.

Ehalt, Rômulo da Silva, "Casuística nos Trópicos: a pragmática teológico-moral de Francisco Rodrigues na Ásia portuguesa (séculos XVI e XVII)", Revista de História da Sociedade e da Cultura 19 (2019): 399-418. 
Ehalt, Rômulo da Silva, "From Tenants to Landlords: Jesuits and Land Ownership in Japan (1552-1614)”, in Županov, Ines G. and Vu Thanh, Hélène (eds.), Conquering New Markets: Trade Routes, Conversion and Mission during the First Globalization (16th-18th c.), Leiden and Boston 2021.

Ehalt, Rômulo da Silva, "Goa no Iezusukai no Shingakusha to Nihon no Doreika Mondai" [Jesuit Theologians of Goa and the Problem of Enslavement in Japan], in Kirishitan Bunka Kenkyūkai Kaihō 154 (2019): 1-14.

Ehalt, Rômulo da Silva, Jesuits and the Problem of Slavery in Early Modern Japan (PhD Thesis), Tokyo 2017.

Fernandes Pinto, Ana and Pires, Silvana Remédio, "The 'Resposta que alguns Padres de Japão mandaram perguntar': a clash of strategies?", in Bulletin of Portuguese-Japanese Studies 10/11 (2005): 9-6o.

Fujii Yoshio, Oshioki-Edo Jidai no Tsumi to Batsu [Punishment: Crime and Punishment in the Edo Period], Tokyo 1983.

Golvers, Noël, "Circulation and Reception of Portuguese Books in the 17th/18th Century Jesuit Mission of China, mainly in Three Bishop's Collections (Diogo Valente, Polycarpo de Sousa and Alexandre de Gouveia)", in Berbara, Maria and Enenkel, Karl A.E. (eds.), Portuguese Humanism and the Republic of Letters, Leiden and Boston 2012, 243-264.

Golvers, Noël, "The Library Catalogue of Diogo Valente's Book Collection in Macao (1633): A Philological and Bibliographical Analysis", in Bulletin of PortugueseJapanese Studies 13 (2006): 7-43.

Gonoi Takashi, Tokugawa Shoki Kirishitan-shi Kenkyū, Hoteiban [Research on Kirishitan History in the Early Tokugawa Period, Revised version], Tokyo 1992.

Hesselink, Reinier H., "104 Voices from Christian Nagasaki - Document of the Rosario Brotherhood of Nagasaki with the Signatures of Its Members (February 1622): An Analysis and Translation", in Monumenta Nipponica 70:2 (2015): 237-283.

Hesselink, Reinier H., "The Capitães Mores of the Japan Voyage: a Group Portrait", in International Journal of Asian Studies 9:1 (2012): 1-41.

Hesselink, Reinier H., The Dream of Christian Nagasaki: World Trade and the Clash of Cultures, 1560-1640, Jefferson (US) 2016.

Hino Hiroshi (ed.), Koryaado Zangeroku-Kirishitan Jidai Nihonjin Shinto no Nikusei [Collado's Confession Manual: The Voice of Japanese Believers during the Kirishitan Period], Tokyo 2016.

Irimoto Masuo, "Jūningumi no Seiritsu" [The Establishment of the Ten-People Group System], in Kitajima Masamoto (ed.), Kinsei no Shihai Taisei to Shakai Kōzō [Early Modern Control Organization and Social Structure], Tokyo 1983, 163-20o.

Irimoto Masuo, Goningumi to Kinsei Sonraku-Rentai Sekininsei no Rekishi [The Five-People Group and The Early Modern Village: The History of Collective Responsibility], Tokyo 2009 . 
Jonsen, Albert R. and Toulmin, Stephen, The Abuse of Casuistry: A History of Moral Reasoning, Berkeley, Los Angeles and London 1988.

Kataoka Yakichi, "Hakugaika no Kirishitan: Nagasaki ni okeru Yadonushi no Gyōseki wo Chushin to shite" [Kirishitan under Persecution: The Work of Hosts in Nagasaki], in Kirishitan Bunka Kenkyūkai Kaihō 6:4 (1963): 7-14.

Katō, Eiichi, "Aspects of Early Anglo-Japanese Relations", in Nish, Ian and Kibata, Yoichi (eds.), The History of Anglo-Japanese Relations, 1600-2000: Volume I: The Political-Diplomatic Dimension, 160o-1930, London and New York 2000, 31-59.

Kawamura, Shinzō, Kirishitan Shinto Soshiki no Tanjō to Henyō: Confraria kara Konfurariya he [The Birth and Changes of Christian Lay Organizations: From Confraria to Konfurariya], Tokyo 2003.

Kawamura Shinzō, Making Christian Lay Communities during the "Christian Century" in Japan: A Case Study of Takata District in Bungo (PhD Thesis), Washington DC 1999.

Klötter, Henning, The Language of the Sangleys: A Chinese Vernacular in Missionary Sources of the Seventeenth Century, Leiden 2011.

Kudamatsu Kazunori, Kirishitan Denraichi no Jinja to Shinkō-Hizen-no-kuni Ōmura-ryō no Baai [Shrines and Belief in Areas of Christian Missions: the case of the Ōmura fief of Hizen], Ōmura (Japan) 2008.

Kudamatsu Kazunori, Nagasaki no Ise Shinkō-Oshi wo meguru Ise to Nishi-Hizen to no Nettowaaku [The Ise Belief in Nagasaki: The Network of Guides Between Ise and East Hizen], Nagasaki 2018.

López Gay, Jesús, El Matrimonio de los Japoneses: Problema, y soluciones según um ms. inédito de Gil de la Mata, S.J. (1547-1599), Rome 1964.

Lucena, Afonso de, De algumas cousas que ainda se alembra o Pe Afonso de Lucena que pertencem à Christandade de Ōmura, ed. Schütte, Josef Franz, Rome 1972.

Marcocci, Giuseppe, "Conscience and Empire: Politics and Moral Theology in the Early Modern Portuguese World", JEMH 18 (2014): 473-494.

Marcocci, L'invenzione di un impero: Politica e cultura nel mondo portoghese (14501600), Rome 2011.

Matsuda Kiichi, Kinsei Shoki Nihon Kankei Nanban Shiryō no Kenkyū [Research on Nanban Sources Related to Early Modern Japan], Tokyo 1981.

Matsui Yōko, “Jendaa kara Miru Kinsei Nihon no Taigai Kankei” [Japan's Early Modern Foreign Relations as Seen from Issues of Gender], in Arano Yasunori (ed.), Nihon no Taigai Kankei 6-Kinsei-teki Sekai no Seijuku [Japan's Foreign Relations 6: The Maturity of the Early Modern World], Tokyo 2010, 93-121.

McManus, Stuart, "Imperial History without Provincial Loyalty? Reading Roman History in Renaissance Japan", KNOW: A Journal on the Formation of Knowledge 3:1 (2019): 123-157.

McManus, Stuart, "Limited-Term Servitude in Early Modern Nagasaki: Slavery and Contract Law in Gomes Vaz's De mancipiis Indicis (1610)", Bulletin of PortugueseJapanese Studies, (2018). 
Menegon, Eugenio, Ancestors, Virgins, \& Friars: Christianity as a Local Religion in Late Imperial China, Cambridge (US) and London (UK) 2009.

Miyazaki Masakatsu, "Esutādo da India to Kapitan Mōru sei: Sekaishi Kyōiku ni okeru Daikōkai Jidai he no Ikkōsatsu" [Estado da Índia and the Capitão-Mor System: Reflections on the Great Navigations in the Teaching of World History], in Tsukuba Daigaku Fuzoku Kōtō Gakkō Kenkyū Kiyō 30 (1989): 7-24.

Murakami Naojirō, "Kirishitan Kenkyū no Kaiko" [Recollections of Kirishitan Research], in Kirishitan Kenkyū 1 (1942): 1-42.

Nawata-Ward, Haruko, Women Religious Leaders in Japan's Christian Century, 1549-1650, Surrey (UK) 2009.

O'Malley, John W., "The Fourth Vow in Its Ignatian Context: A historical context", in Studies in the Spirituality of Jesuits XV, 1 (1983): 1-59.

Odstrčilík, Jan, “Between Languages, Genres and Cultures: Diego Collado's Linguistic Works", in medieval worlds 11 (2020): 117-151.

Ōmura-shishi Hensan Iinkai (ed.), Shin'hen Ōmura-shishi 3 , Kinsei-hen [New History of the City of Ōmura 2, Early Modern], Ōmura (Japan) 2015.

Pagès, Léon, Histoire de la religion chrétienne au Japon, depuis 1598 jusqu'à 1651, comprenant les faits relatifs aux deux cent cinq martyrs béatifiés le 7 juillet 1867, 1, Paris 1869 .

Prosperi, Adriano, "The missionary”, in Villari, Rosario (ed.), Baroque Personae, Chicago and London 1991, 160-194.

Ramos, Martin Nogueira, "Renier sa foi sans perdre son âme. Les catholiques japonais au début de la proscription (XVIIe s.)", in Cahiers d'études des cultures ibériques et latinoaméricaines 5 (2019): 177-2O2.

Ramos, Martin Nogueira, La foi des ancêtres: Chrétiens cachés et catholiques dans la société villageoise japonaise XVIIe-XIXe siècles, Paris 2019.

Rolbiecki, John J., "Casuistry”, in Dagobert Runes (ed.), Dictionary of Philosophy, New York 1971, 46.

Ross, Andrew C., A Vision Betrayed: The Jesuits in Japan and China, 1542-1742, Edinburgh 1994.

Ruiz-de-Medina, Juan, El Martirologio del Japón 1558-1873, Rome 1999.

Sá, Isabel dos Guimarães, As Misericórdias Portuguesas de D. Manuel I a Pombal, Lisbon 2001.

Sá, Isabel dos Guimarães, História Breve das Misericórdias Portuguesas (1498-2000), Coimbra 2008.

Sales, Maria de Lurdes Ponce Edra de Aboim, Do Malabar às Molucas: os Jesuítas e a Província do Malabar (1601-1693) (PhD Thesis), Lisbon 2015.

Schütte, Josef Franz, "Futatsu no Komonjo ni Arawaretaru Nihon Shoki Kirishitan Jidai ni Okeru 'Santa Maria no Onkumi' no Soshiki ni tsuite" [On the structure of the Santa Maria no Onkumi during the early Kirishitan period of Japan as seen in two documents], in Kirishitan Kenkyū 2 (1944): 135-47. 
Schüssler, Rudolf, The Debate on Probable Opinions in the Scholastic Tradition, Leiden 2019 .

Schütte, Josef Franz, Introductio ad Historiam Societatis Jesu in Japonia 1549-1650, Rome 1968.

Schütte, Josef Franz, Monumenta Historica Japoniae I: Textus Catalogorum Japoniae Aliaeque de Personis Domibusque S.J. in Japonia, Informationes et Relationes, 1549-1654, Rome 1975 .

Shimizu Kōichi, Kisaki Hiromi, Yanagida Mitsuhiro and Ujie Takeshi (eds.), Kinsei Nagasaki Hōsei Shiryōshū 1 [Legal Documents of Early Modern Nagasaki], Tokyo 2014.

Takase Kōichirō, "Kirishitan Fukyō ni okeru Usura Chōshū no Mondai ni tsuite" [On the problem of collecting usury against the background of the Christian mission] in Shigaku [History] 6o.4 (1991): 25(429)-57(461).

Tronu, Carla, "The Rivalry between the Society of Jesus and the Mendicant Orders in Early Modern Nagasaki", in Agora:Journal of International Center for Regional Studies 12 (2015): 25-39.

Tutino, Stefania, Uncertainty in Post-Reformation Catholicism: A History of Probabilism, Oxford 2018.

Vu Thanh, Hélène, "Introducing Tridentine Marriage: The Jesuits' Strategy in Japan (Sixteenth and Seventeenth Centuries)", Rechtsgeschichte - Legal History 27 (2019): 143-151.

Vu Thanh, Hélène, "Principles of Missionary Geography in Jesuit Spirituality and their Implementation in Japan (16th-17th centuries)", in Bulletin of Portuguese/Japanese Studies 18/19 (2009): 175-191.

Wicki, Josef, "Problemas morais no Oriente Português do século XVI", in O Centro de Estudos Históricos Ultramarinos e as Comemorações Henriquinas, Lisbon 1961, 257263 .

Yamamoto Hirofumi, Tokugawa Hidetada, Tokyo 2020.

Yasutaka Hiroaki, Kinsei Nagasaki Shihōseido no Kenkyū [Research on the History of the Legal System of Early Modern Nagasaki], Kyoto 2010.

Zagorin, Perez, Ways of Lying: Dissimulation, Persecution, and Conformity in Early Modern Europe, Cambridge (US) and London (UK) 1990. 